\title{
Public Services between the Citizen's Need and the Possibilities of the Administration
}

Adriana GRIGORESCU, National University of Political Studies and Public Administration, Bucharest, Romania; Correspondent Member of the Academy of Romanian Scientists adriana.grigorescu@snspa.ro

\begin{abstract}
This paper aims at the balance between the citizen and the public authorities with public services as an interface. Public services place themselves at the crossroads of many elements such as: needs of the citizen, social need, public will, public resources, private availability, and civic sense. Without claiming to have identified all factors that converge to defining / structuring the public services (PS) / services of general interest (SGI), the paper tried to highlight some of the most important.

The social need is covered at the macro level and it represents what society - as a whole - needs. Citizens' needs are more specific, individualized and custom-designed, rundown by gender, age, education, social condition, financial strength, religion, living environment etc. The public will is an expression of what the Administration encompasses in mid-and long-term national strategies and addresses in detail the PS / SGI in sectorial policies where responsibility is assumed. Public resources include in our assessment all resources at the disposal of the Administration at some point. Private availability can be expressed through various forms such as public-private partnerships, development of complementary private sponsorships, donations etc.

A balanced public service can also benefit of citizens' civic sense. Even if they are completely satisfied with the services at hand they understand that it would be without sense to unnecessary ask for them just only because it's free.
\end{abstract}

Keywords: Public services, citizen expectation, public capacity, quality

JEL Classification: M31, M10, D91, L32

\section{Introduction}

Obviously one goal for the citizen, but also for the authorities should be the "perfect mix" of each public service. Defining such a "perfect mix" would lead to "an ideal level" to be reached. By properly adjusting "the archetype", one could 
get 2-3 alternatives to be submitted for public debate in order to detect citizens' standpoints towards an issue.

One of citizens' expectations is related to providing quality the public services (PS) / services of general interest (SGI), free, at low prices, or partially subsidized. The main concern of the Administration should be directed towards PS/SIG users, their requirements and expectations.

Public authorities with responsibilities in the design and supply of PS / SGI must act in full transparency. This involves recognizing citizens' needs for which the services were designed, what they consist of, who is responsible for providing them and under what terms. In other words, what are the obligations the Administration is assuming and in which way are these going to be met? PS Systems / SGI must be consistently designed and should aim at supporting people and implementing national strategies and policies (Lall and Lundberg, 2006).

Cohabitation between state and private suppliers enables the Administration to design effective and competitive systems, and to decrease investment efforts. Informing citizens on all elements inspiring public decisions with respect to SG / SGI is a vital element in building a relationship citizen-solid authority based on trust and mutual respect.

The definition of public services over time has undergone significant changes, with the slogan being that of services of general interest precisely in order to allow the private sector to penetrate the public service area. At present, public service implies the fulfillment of three major criteria: (1) The material element - Public service is an activity that responds to a need in the general interest; any activity of general interest; (2) The formal element - The performance of the activity is subject to a specific legal regime and is ensured by a public person; (3) The volunteer element - Depends on the will of the public and their power of decision and creating the way of management and functioning. The characteristics of public services are: they satisfy a social need; they are carried out as a public utility activity; their legal regime is governed by rules of public law; provision is made through public institutions; they have a permanent character and are constantly in a legal relationship; the public service must be executed irrespective of costs (Plumb, Androniceanu, Abaluta, 2003). In this sense that, the term "services of general interest" becomes more comprehensive by bringing together both public services and those provided by private legal entities.

At the same time, the European Commission (EC COM/2000/0580) defines market and non-market services as a service of general interest, a service that public authorities classify as being of general interest and subject to specific public service obligations (eg transport, energy, communications). In the 
Commission's view, the term public service is ambiguous, also referring to the legal status of the supplier.

\section{General environment structure}

The present paper aims to examine a less conceptual differentiation between the two concepts but essentially the relationship of the citizen with the public authorities while having the public services as an interface. The term public service or service of general interest (PS / SGI) will be used in its classical concept of the early 20th century (Duguit, 1922), according to which the civil service is "the activity that the governors are obliged to perform in the interests of the governed".

Fig. no. 1 Influence factors of Public Services

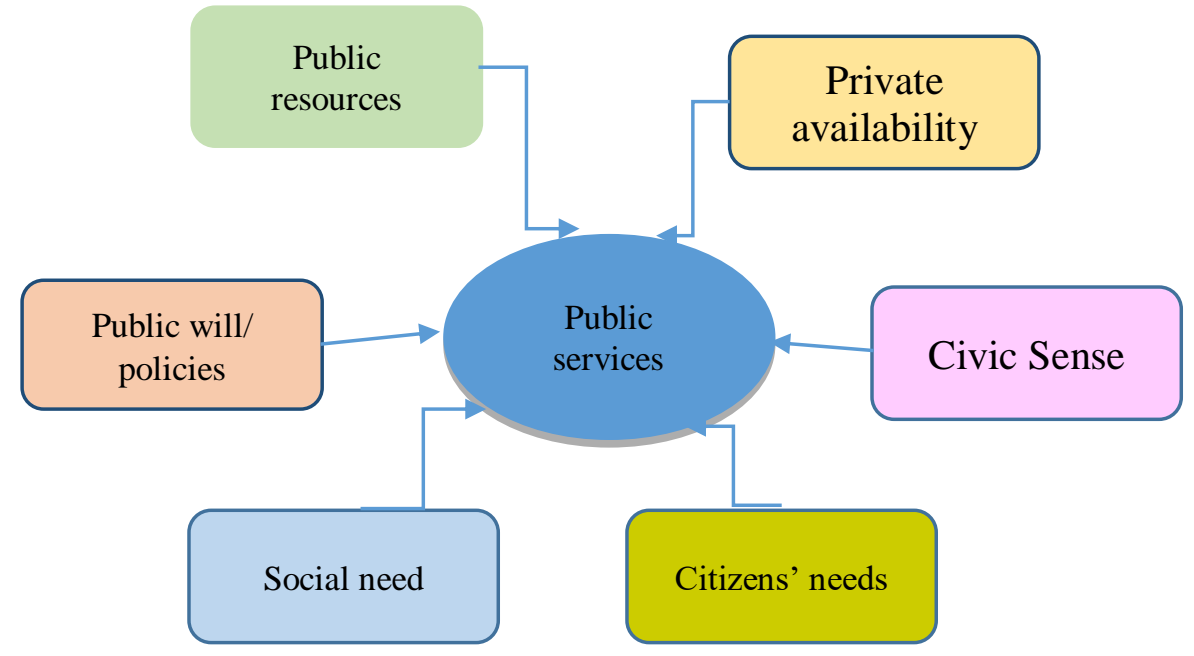

Source: Author view

The European Commission declares the citizen's interest as the core element of the PS / SGI mission. Public services are placed on the incidence of several elements such as: citizens' needs, social need, public will, public resources, private availability, and civic sense (Figure no.1). Without claiming to identify all the factors that converge to the definition / structuring of PS / SGI, we consider that we have highlighted even the most important. Thus, social need is differentiated by the need of citizensstarting from the consideration that social need is not the sum of individual needs.

Social need is determined at the macro level and represents what society as a whole needs. An example of this may be the need for education, all citizens 
could benefit from the right to education. The fact that a citizen is very rich does not mean that he does not have the right to send his children to the public education system (Warren Edward Buffett case). But he can act through other levers to support the system, such as donations (civic sense) or involvement as a private investor. Thus, the social need comprises those services to which the citizen has the right and which the society as a whole benefits in order to ensure social equilibrium, social development and current well-being.

Citizens' needs are more specific, individualized and customized, differentiated by gender, age, education, social conditions, financial strength, religion, living environment, etc. The citizen's need must be identified as accurately as possible and establish the segments of citizens to which the State must orientate the custom PS / SGI.

Public will is the expression that the administration encompasses in the Medium and Long Term National Strategy and details in Sectoral Policies as PS / SGI for which it assumes responsibility. Although theory says "there are no public services by their very nature," we cannot totally agree with it based on fundamental human rights. Thus, the International Charter of Human Rights and related legislation states' rights such as: The right to life, the right to health and the right to a healthy environment; Right to education and access to culture; Citizen's right to safety; The right of defense and the principle of nondiscriminatory access to justice; and specific rights (1) Protection of children and young people; (2) Protection of persons with disabilities; (3) Right to petition. In our view, public will must be related to these fundamental elements when defining the PS/ SGI system.

Public resources include, in our opinion, all the resources that public administration has at a certain time. Their importance in the PS / SGI delimitation is that it is a feature of these services that they are provided at any cost. It is therefore necessary for the State, in its capacity as a system manager, to correlate the structure and size of the PS / SGI with the resources available to ensure their delivery. It can use the partial cost transfer to the citizen, to attract private funding or to associate and dilute the investment effort. It also has the possibility of "controlled" transfer in the area of market services and the inclusion of the private sector as potential suppliers.

Private availability can be expressed through various forms such as publicprivate partnership, the development of a complementary private structure, sponsorships, donations, etc. In situations where the state does not have the resources needed to provide an appropriate public service, it can appeal to the private sector both as a methodology, infrastructure, and resources. Some public services may be transferred to private operators operating under market mechanisms but rules may be laid down to limit such activities so as not to affect 
the free and non-discriminatory access of all citizens.

A balanced system of public services can also benefit the citizens' civic sense, who will be pleased with the services they receive and will understand that it is inappropriate to demand, even if they do not need, certain services just because they are free of charge. The citizen will know or will be educated to know their rights regarding the public services they can benefit from and the way they can call them. The citizen is the first vector of financial support of the state budget through their contributions (income tax, property tax, other local taxes and contributions to various funds). At present, the citizen only has a contribution of about $30 \%$, the employer also having a similar contribution. Their dissatisfaction with public services will be reflected in the desire, in our opinion, to diminish these contributions. Based on OUG 79/2017 all contributions are transferred to the employee, to ensure better collection, based on the previous experience that shows a higher responsibility of the citizen than the private companies.

Could be seen that the identified factors are working in pairs Social need Citizen's needs; Public will - Public resources and Private availability - Civic sense. The intersection of them and a balanced system of PS could be the solution to reach the citizen satisfaction as it is presented in figure 2 .

Fig. no. 2 Potential mechanism of a balanced system of PS

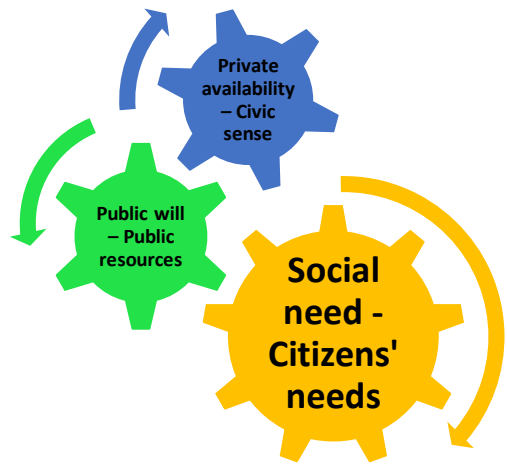

\section{Source: Author view}

Using the civic sense and creating pressure on institutions government can collect a larger amount of funds, so the contribution from the state budget to be less and reoriented to other priorities. Having larger resources the public will can be easier applicable and cover more of the social need. 
3. Balanced system of public services

One aspect to be emphasized is: What must be understood by a decent public service that would please the citizen? No matter how many resources are available the PS will be placed between a minimal limit of what we are named as "decent PS" and a maximal level named "regular PS". None of the PS will be placed on the area or "special", "luxury" etc.

In our opinion, this aspect has to be analyzed from the perspective of the five components of the marketing mix: (1) the product; (2) personnel; (3) price; (4) distribution; (5) promotion (Grigorescu, 2006). Marketing theory and practice and marketing mix being able to offer optimal marketing mixes to support a balanced system of PS and to facilitate the public and the private suppliers.

At the same time, marketing theory proposes to approach different segments with different specific mixes to meet their expectations. If the private sector, in the provision of services identifies different segments that have similar characteristics and expectations to determine their purchasing decision, the segments for public services are, categories of citizens to whom the state must act differently (Aaberge \& all, 2010).

It may be natural to ask why we have delineated an "incidence area" and do not analyze the convergence of elements in specific pairs (figure no.3). The reason is that the elements of the marketing mix are interdependent. Thus, the price is sensitive to the level of quality that it offered, the number of employees affects the quality, the cost and the distribution of the product. Promoting / communicating with the customer is reflected in product definition, costs and the relationship with the citizen (Grigorescu, Bob, Dobrescu, 2007).

Obviously a desiderate of citizens and authorities should be the "perfect mix" of every public service. This should refer to the most comprehensive product that allows for the implementation of national strategies and policies of high quality (without regard to luxury quality). 
Fig. no. 2 Incidence of marketing mixes in public services

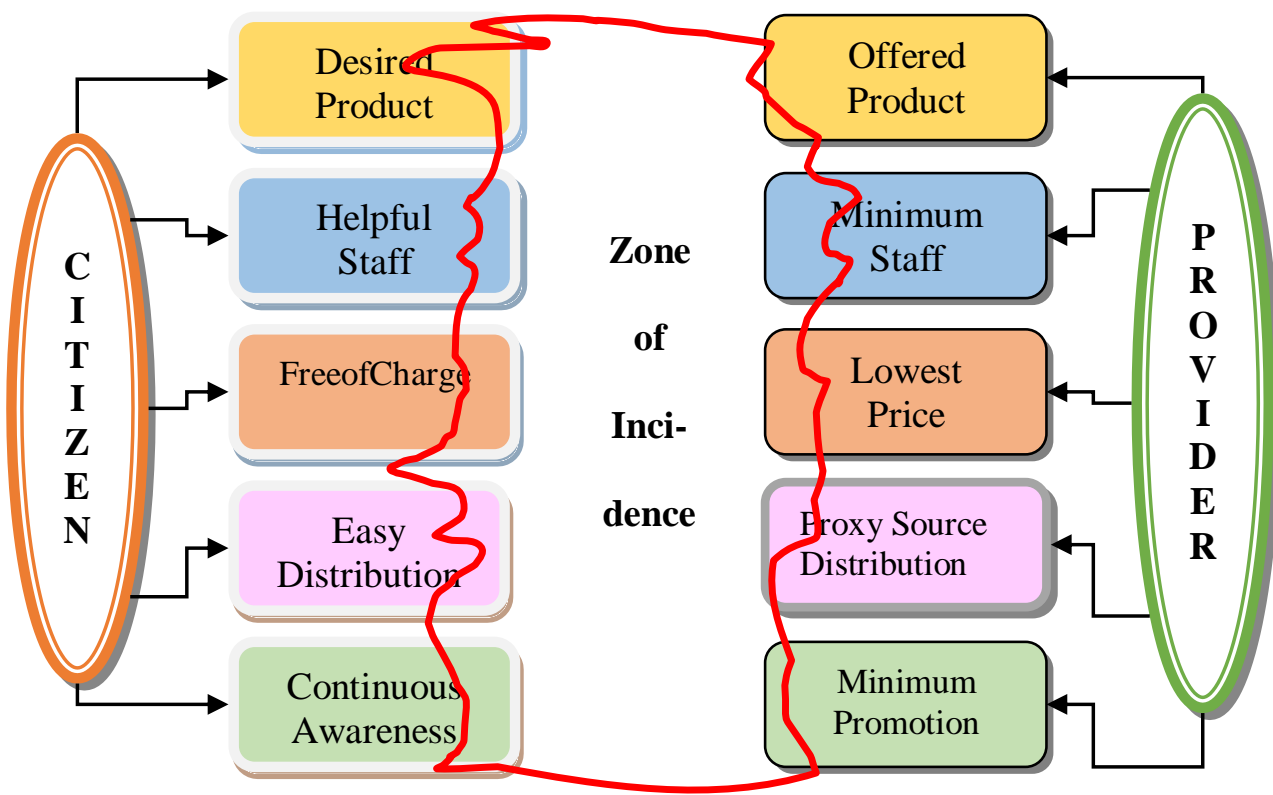

Source: Author view

These policies should be based on international standards in terms of offering technologies, with the help of highly motivated personnel, free of charge for all citizens in the best environmentally friendly conditions of supply, using modern equipment, obviously there is the possibility of continuous information for the beneficiary about the services, easy way to access and the benefits of using the service respectively.

The definition of such a "perfect mix" would allow the establishment of an idealistic level of achievement from which, through appropriate adjustments, 2-3 variants of the public debate could be proposed in order to know the position of the citizens in relation to them.

Very important elements in the PS / SGI design are also mentioned in the European Commission document COM / 2000/0580 final. This shows an important contribution to the overall competitiveness of the European industry on economic, social and territorial cohesion. The provision of PS / SGI at a higher quality level and under easy access both in terms of cost and procedure forces the private sector that provides complementary services or acts as an option in the system to comply with a certain standard. At the same time, the 
requirements imposed in the situation of the transfer to the public sector of PS / SGI must be placed at a level of the requirements that the state wishes to provide to the citizens. The national PS / SGI systems contribute to the elimination of discrepancies resulting from different economic and social developments in different regions, ensuring the decent living conditions for citizens (especially the disadvantaged).

One of the citizens' expectations is to provide free, low-quality, or partially subsidized PS / SGI. The main concern of the administration should be the PS / SGI users, their requirements and expectations.

Public authorities charged with designing and delivering PS / SGI must act in full transparency (Stirton and Lodge, 2001). This implies highlighting the needs of the citizens for whom the services are designed, what they are, who is responsible for providing them and under what conditions. In other words, what are the responsibilities the administration assumes and how it will honor them? PS / SGI systems need to be coherently designed and aimed at supporting citizens and implementing national strategies and policies.

\section{Case study - healthcare}

A better understanding of the area of incidence between citizens' expectations and the possibilities of the GS / GG administration is believed to be achieved by exemplifying it. To be relevant, we set up a panel of 23 subjects to whom we asked for a description of the public health service and the educational service from the perspective of the citizen, the real or hypothetical beneficiary and the administration, i.e. the provider. The panel was interviewed in October 2009 - March 2010 and subject were selected from various geographic areas, rural and urban, various ages, professions, income level, level of education and

We are presenting a couple of opinions that we considered relevant, without being a synthesis or a processing of the opinions we received. 
Table no. 1 Balanced marketing mix (expectation - offer)

\begin{tabular}{|c|c|c|}
\hline & Citizen - Beneficiary & Administration - Provider \\
\hline Product & \multicolumn{2}{|c|}{ Medical Assistance or Healthcare } \\
\hline Premise & $\begin{array}{l}\text { - Improving the health of the } \\
\text { population, increasing the quality } \\
\text { of life. } \\
\text { - approving the national strategy } \\
\text { for the development of sanitary } \\
\text { services for a minimum of } 8 \text { years. } \\
\text { - the development of disease } \\
\text { prevention and early detection } \\
\text { programs. } \\
\text { - Recovery and development of } \\
\text { rural health care. } \\
\text { - ensuring transparency in the } \\
\text { spending of public money. }\end{array}$ & $\begin{array}{l}\text { - Ensure a system of population health } \\
\text { surveillance. } \\
\text { - prevention of disease, epidemics, } \\
\text { pandemics. } \\
\text { - developing a high-performing } \\
\text { healthcare network. } \\
\text { - providing medical care for special } \\
\text { categories. } \\
\text { - protection of mother and child. } \\
\text { - implementing family planning policies. } \\
\text { - Maintaining high levels of health in the } \\
\text { active population }\end{array}$ \\
\hline $\begin{array}{c}\text { Target } \\
\text { segments }\end{array}$ & All citizens & $\begin{array}{l}\text { - children (0-7 years old) } \\
\text { - pupils and students } \\
\text { - Active people } \\
\text { - retired } \\
\text { - uninsured persons } \\
\text { - special categories }\end{array}$ \\
\hline $\begin{array}{c}\text { Technical } \\
\text { description of } \\
\text { the product }\end{array}$ & $\begin{array}{l}\text { - providing all medical and health } \\
\text { care services, except. - free of } \\
\text { charge for a physician or } 80 \% \\
\text { compensation. - free vaccination. - } \\
\text { free laboratory and imaging } \\
\text { analysis. }\end{array}$ & $\begin{array}{l}\text { - health care and prevention for all } \\
\text { categories. - Minimum health } \\
\text { surveillance package by target } \\
\text { categories. - Emergency healthcare and } \\
\text { minimal care needed to maintain } \\
\text { population health - differentiated by } \\
\text { category. - physiological explorations } \\
\text { (current / usual and imaging laboratory } \\
\text { tests). - physiotherapy and balneology } \\
\text { treatments } 2 \text { packages per year. - } \\
\text { specialized medical assistance (consult a } \\
\text { specialist, operations, treatments, etc.). - } \\
\text { family planning counseling. - free or } \\
\text { compensated drugs - by categories of } \\
\text { assistants. }\end{array}$ \\
\hline
\end{tabular}




\begin{tabular}{|c|c|c|}
\hline Quality & $\begin{array}{l}\text { - safe (to avoid harm to patients } \\
\text { by health services that should help } \\
\text { them); } \\
\text { - Effective (services should be } \\
\text { based on scientific knowledge for } \\
\text { all who could benefit and restrict } \\
\text { the provision of services to those } \\
\text { who most likely will not benefit, } \\
\text { thus avoiding both overuse and } \\
\text { under-use); } \\
\text { - prompt (reduce waiting times } \\
\text { and delays for both receiving and } \\
\text { providing healthcare); } \\
\text { - Effective (avoid losses, including } \\
\text { equipment loss, ideas and energy) }\end{array}$ & $\begin{array}{l}\text { - according to the WHO provisions, } \\
\text { European standards and the provisions } \\
\text { of the legislation in force. } \\
\text { - prompt - to be delivered as soon as } \\
\text { possible after the request. } \\
\text { - safe - that is, to be carried out in } \\
\text { hygienic and safe conditions. } \\
\text { - with high professionalism. }\end{array}$ \\
\hline Costs & $\begin{array}{l}\text {-Free of Charge } \\
\text {-Compensated } 80 \%\end{array}$ & $\begin{array}{l}\text { - free of charge } \\
\text { - partially subsidized } \\
\text { - compensated between } 50 \text { and } 90 \% \\
\text { - paid in full }\end{array}$ \\
\hline $\begin{array}{c}\text { Access } \\
\text { Methodology }\end{array}$ & -Simple & $\begin{array}{l}\text { - On the basis of the ID card and the } \\
\text { annual health insurance certificate } \\
\text { stating the category. }\end{array}$ \\
\hline $\begin{array}{l}\text { Informing } \\
\text { the } \\
\text { population }\end{array}$ & & $\begin{array}{l}\text {-Information programs } \\
\text {-Annual surveys }\end{array}$ \\
\hline
\end{tabular}

Source: collected information from the subjects

Discrepancies can be noticed between the two approaches, naturally due to the two positions represented, although both are formulated by two subjects as citizens and with public sector attributions. Essentially, the differences result from the limited perspective on the subject, a limitation that leads to the impossibility of embracing a whole system.

One view would lead to the idea that citizens are waiting for a public health service to be entrusted to the administration, to have a fully funded minimum component (free of charge) and a partially compensated component, as well as a category identified as services that can be paid for.

What deepens misunderstanding and disarmament between the citizen and authority is the lack of regulation and long-term stability. Harmonizing the interests of the two sides is fundamental to the well-being of society (Curtice and Patrikios, 2009). 


\section{Incidence area of the marketing mix /Conclusions}

The European Commission (EC COM 2000/0580) highlights a number of issues that we want to present and integrate in the context of establishing the incidence area.

1 - 'Users' needs should be broadly defined for those consumers who clearly play an important role. For consumers, a guarantee of universal access, high quality and accessibility (from a cost perspective) is the basis of their needs.

Citizens' concerns are also broader, such as:

- High level of environmental protection;

- Specific needs of certain categories of population, such as people with disabilities and those with low incomes;

- Full territorial coverage of essential services in isolated or inaccessible areas".

It should be noted that starting with the needs of citizens that are on a large-scale evaluation can be used as an inventory for other aspects relevant to the system. At the same time, elements of non-discrimination and access to all PS / SGI for citizens, with emphasis on their quality and accessibility.

2- "A set of principles can help define users' needs for services of general interest. These principles include:

- Clear definition of the basic obligations to ensure the provision of good quality services, high levels of public health and the physical safety of services;

- Full transparency, for example on tariffs, contract terms and conditions, supplier selection and financing;

- The choice of services and where appropriate the choice of supplier and the existence of real competition between suppliers;

- The existence, in justified cases, of regulatory bodies independent of operators and remedies in the form of dealing with complaints and dispute settlement mechanisms;

They may also include active representation and participation of users in defining services and choosing forms of payment."

The co-existence of state and private suppliers allows the authority to design competitive, efficient systems and reduce its investment effort. Informing citizens about all the elements underlying the public decision on the PS / SGI is a key element in building a citizen-authority relationship on a solid basis of trust and mutual respect.

In the last years various solution were used and the PS were improved by mixing the public and private suppliers (Grigorescu, A., De Freitas Bradley C., 
Ivascu, M., 2016). We are considering that there is unexplored potential of marketing mix to contribute to a balanced system for all PS or SGI.

\section{References}

[1] Aaberge, R., Bhuller, M., Langørgen, A. and Mogstad, M., 2010. The Distributional Impact of Public Services When Needs Differ, IZA Discussion Paper No. 4826.

[2] Curtice, J. K. and Patrikios, S., 2009. Locked In and Silent? The Effectiveness of 'Voice' in Public Services Reform, APSA 2009 Toronto Meeting Paper.

[3] Duguit, L., 1922. Concept of Public Service. Yale LJ, 32, pp.425.

[4] Grigorescu, A., 2006. Marketing of public and private affairs-a link. Kybernetes, 35(7/8), pp.1179-1189.

[5] Grigorescu, A., Bob, C.A. and Dobrescu, E.M., 2007. Marketingul afacerilor publice şi private. Bucureşti: Editura Uranus.

[6] Grigorescu, A., De Freitas Bradley C., Ivascu, M., 2016. Re-Modelling The Healthcare System Using Two Poles - Quality Of Healthcare Services And Patient Satisfaction, Proceedings of BASIQ, pp. 142-150.

[7] Lall, S.V. and Lundberg, M., 2006. What are Public Services Worth, and to Whom?Nonparametric Estimation of Capitalization in Pune. World Bank Policy Research Working Paper No. 3924.

[8] Plumb, I., Androniceanu, A. and Abaluta, O., 2003. Managementul serviciilor publice. Bucureşti: Editura ASE, pp. 83-85.

[9] Stirton, L. J. and Lodge, M., 2001. Transparency Mechanisms: Building Publicness into Public Services.Journal of Law and Society, 28(4), pp. 471-489.

[10] European Commission, Communication from the Commission - Services of general interest in Europe/ COM/2000/0580 final online https://eur-lex.europa.eu/legalcontent/EN/TXT/?uri=celex\%3A52000DC0580[Accessed 12 February 2010].

${ }^{1}$ Author note and acknowledgement

\footnotetext{
${ }^{1}$ The first version of the paper was Annual Seminar of Scientific Research, Public administration and political environment. Perspectives of a Good Governance. Institute of Administrative Sciences „Paul Negulescu” \& Romanian-German University from Sibiu, May 27-29, 2010 and was published in CAIETUL ŞTIINTIFIC al I.S.A. „Paul Negulescu” no.12/2010 in Romanian language. Due to the great interest resulting from accessing the abstract and the full text, I decided to translate and publish this version. Paper was presented at the International Conference BASIQ 2018, Heidelberg, Germany.
} 